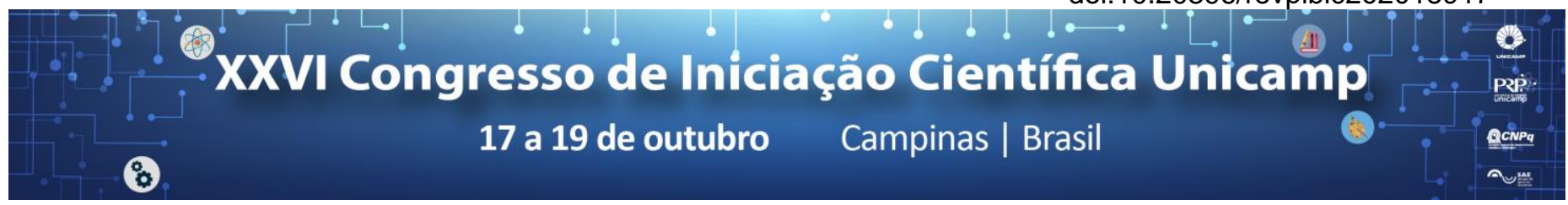

\title{
Interpretations of the Spinoza's Monism
}

\section{Luis F. A. Oliveira, Marcio Augusto Damin Custodio}

\begin{abstract}
The purpose of this research is to analyse two distinct readings of Spinoza's metaphysics made by two great interpreters of the twentieth century: Curley and Wolfson. The first is treated through logical terms and the relation that the propositions of Spinoza's Ethics have among them, explaining the relationship between the author and Cartesianism of his time. The second is treated through a detailed philology of a tradition of texts prior to the author, explaining the relationship beteween Spinoza and the Jewish Medieval Aristotelian tradition.
\end{abstract}

Key words: Monism, Indivituation, Substance.

\section{Introduction}

There is no consensus among contemporty readers on how Spinoza brings his notion of a single substance. In this respect, it is possible to identify two main interpretative lines, originally proposed by Curley and Wolfson. Curley's perspective is based on the principle of individuation, ie., the finite bodies cannot been called substance because of their characteristics of individuation. The author maintains that Spinoza's monism is an extrapolation of the definition of substance that Descartes provides in the Principles, in which, truthly, only God can be substance, excluding the finite bodies, once that susbtance is "that which is conceived by itself". Wolfson's perspective is based on the revision of the notion of substance, holding that the Spinoza's monism is a reformulation of the traditional notion of substance contained in the Jewish Aristotelians Medieval philosophers.

\section{Results and Discussion}

Acording to Curley, the Spinoza's monism is a direct answer to the Descartes' philosophy which has start with the difference between the individuation of the bodies. To prove this point Curley does the following logical relation: $\mathrm{P} 4 \rightarrow \mathrm{P} 5 \rightarrow \mathrm{P} 14$. For the author, starting whit the proposition 4 of Spinoza's Ethics we can got there in the assertion of monismo (P14) with the help of P5. The proposition 4 afirms that "two or more things are distincts one from another or by a difference in the attributes or by a difference in the afections of a substance", fact that leads Spinoza closer to the cartesian tradition. On the other hand, the proposition 5 holds that is impossible that bodies differentiate by the afections of a substance, since that diferent bodies can be distincts even if they are on the same mode. Finaly, by doing the logical relation between P4 and P5, we can derive directly P14, which affirms that there only can be one substance and this substance is God.

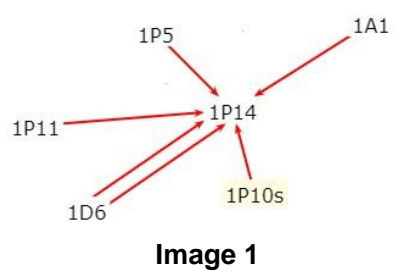

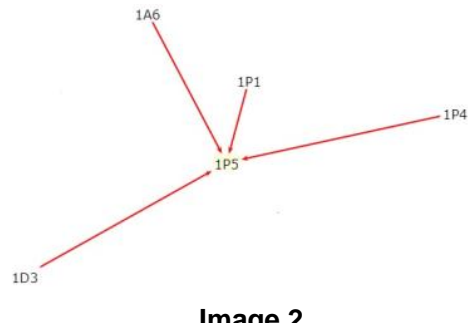

Image 2

We can see at the P14 and P5 "maps" that really exists a relation between the propositions cited by Curley. In fact, the construction of monism is possibly an extrapolation of the Cartesian philosophy.

In the Wolfson's case, in reanalyzing the traditional Aristotelian notion of substance, we have that particular finite bodies can not be substance, which makes God the only being apt to be it. Spinoza holds that substance is "that which exists and is conceived by itself", so, God is the only being, by defition, who meets this, which makes it the only thing possible to be a substance. Wolfson see in tradional notion of substance the starting point of the Spinoza's monism. the only thing Spinoza would have done was to take that notion seriously. we can see in the scheme below the structuring of Spinoza's subtance just as his radical appropriation of Aristotelianism made him, acording to Wolfson.

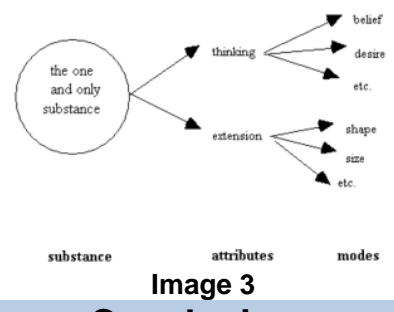

\section{Conclusions}

Both of intepratatives views are strongly based in texts of tradition which Spinoza has acessed, so it is the reader's task to decide which one is closest to the author's text.

\section{Acknowledgement}

I thank to PIBIC, CNPq, SAE and UNICAMP for funding this research; to Professor Márcio to for guiding me and believing in my potential; and to Cleyton and Diego, my good friends, who helped me in several moments.

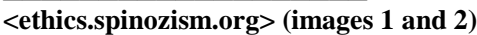

<thedialogues.xyz> (image 3).

GEBHARDT, C (Ed.). 1972. Spinoza opera. v. 1-4. Heidelberg: Carl Winters. 